SUMMARY

I. The construction is described of a simple constant-temperature room for rearing young chicks used in small-scale laboratory experiments.

2. The internal dimensions were $7 \mathrm{ft}$. 0 in. $\times 5 \mathrm{ft}$. 0 in. $\times 9 \mathrm{ft} .6$ in., and this size proved adequate to contain a rack of twenty-four small laboratory cages.

3. The temperature variation was within $\pm 1 \cdot 5^{\circ} \mathrm{F}$. throughout the room.

4. Young chicks were successfully reared in the room from hatching to 4 weeks of age.

\title{
REFFRENCE
}

Barott, H. G. \& Pringle, E. M. (1949). f. Nutrit. 37, 153.

\section{The Use of Chicks for the Biological Assay of Members of the Vitamin B Complex}

\section{Tests with Pure Substances}

\author{
By M. E. COA'TES, S. K. KON AND E. E. SHEPHEARD \\ Cod-Liver Oil (Poultry) Standardization Laboratory, National Institute for \\ Research in Dairying, University of Reading \\ and the Agricultural Research Council
}

(Received 10 May 1950)

During recent years rapid developments in the isolation and identification of the various B-complex vitamins have called for reliable methods of determining these factors and for some means of estimating their physiological availability. Chemical determinations have proved possible for aneurin, riboflavin and nicotinic acid, but the methods, although they may be perfectly reliable for the pure vitamins, are of questionable specificity with naturally occurring materials, as the chemical reactions may be masked, inhibited or enhanced by interfering substances or may fail to detect the vitamin if it is present in a bound form.

The advancing knowledge of the nutrient requirements of micro-organisms has presented a means of measuring certain food factors essential to them; the foundations of the present-day technique of microbiological assay were laid by Snell \& Strong (1939), who used the production of lactic acid by Lactobacillus casei as a measure of response to riboflavin. Many procedures involving different organisms and conditions are now in current use.

The apparent simplicity of these methods has resulted in their widespread application to determinations of vitamins in a great variety of natural materials, and sometimes more confidence has been placed in the results than seemed justified. Although the methods have to some extent been checked by chemical or biological means, no consistent examination of their validity has so far been made, and it was largely to provide 
a biological check for results by microbiological assay that the work reported here was begun.

Microbiological techniques, in common with chemical methods, can only rarely be directly applied to the assay of natural materials. Some preliminary treatment of the sample is usually necessary, involving an extraction process; this may fail to remove completely the vitamin to be measured or may be so drastic as to alter it profoundly or free it from a combined state in which it is not available to animals. It is now generally recognized that the total amount of a vitamin present in a food may differ markedly from the amount available to an animal and that it is only by biological assay that such a difference may be detected. Harris (1948-9) has recently ably reviewed some underlying causes of such discrepancies.

The rat has usually been the animal of choice for nutritional biological tests, but its ability to dispense with an extraneous source of some members of the vitamin $B_{2}$ complex has limited its usefulness. It is normally able to do without exogenous nicotinic acid either because of the activity of its intestinal flora or because it can use tryptophan instead. Hence the suggested tests for this vitamin have depended on increasing the nicotinic-acid requirements of the animal by including a high proportion of maize in the diet. Successful assays with rats have been carried out for riboflavin and pyridoxin, but they are time-consuming, 6-8 weeks being needed for deficiency signs to appear. No reliable test with rats has yet been devised for the 'newer' members of the vitamin $B_{2}$ complex, some of which are synthesized to an appreciable extent by bacterial activity in the rat's intestine.

It seemed probable that the chick would be more suitable than the rat for biological standardization of the water-soluble vitamins. From the first day of its life, the chick is nutritionally independent of the mother except for certain reserves in the yolk-sac, and it can be given an experimental diet immediately after hatching. The rapid growth rate of the chick indicates that its requirements for the water-soluble vitamins may be high and our experience agrees with this view. According to Jukes \& Stokstad (1948) 'chicks appear to derive very little of their vitamin B-complex requirement from "intestinal synthesis" "; unpublished work in this laboratory supports their view.

One of the factors contributing most to the error of a biological assay is the variation between animals; it can be considerably reduced if large numbers from a uniform strain can be used. Chicks are readily available in large numbers, and their cost is low, especially if use is made of surplus cockerels; when purchased from a reputable hatchery, they are generally from a fairly homogeneous stock.

Chicks have been used in the past for the biological assay of some members of the vitamin B complex: vitamin $B_{1}$ (Arnold \& Elvehjem, 1938; Jukes \& Heitman, 1940), riboflavin (Jukes, I937), pantothenic acid (Jukes, I94I), vitamin $B_{6}$ (Sarma, Snell \& Elvehjem, 1946) and folic acid (Lillie \& Briggs, 1947). The diets used in the earlier work were far from pure. Although with the improved knowledge of the chick's nutrient requirements later workers designed more adequate 'synthetic diets', as far as we know none of these methods has been subjected to thorough statistical analysis, and no attempt has been made to assess their accuracy.

In the present work the aim has been to devise a general method that could be 
adapted to the determination of as many different vitamins as possible, and to choose a diet with components of known chemical composition whose quality could be standardized. The results were submitted to statistical analysis, and the experiments were designed to yield the maximal amount of data for such an analysis, although to do this it was necessary to use rather larger numbers of birds than might be required for a routine biological assay.

\section{EXPERIMENTAL AND RESULTS}

\section{Part 1. General methods}

Management of the birds. Sex-linked Rhode Island Red $\times$ Light Sussex cockerels, bred by the Agricultural Research Council's Field Station, Compton, Berkshire, were used throughout the investigations. They were housed in Hearson three-tier electrically heated brooders (Spratts Patent Ltd.) of a pattern commonly used in commercial poultry farms. The temperature of the hover was maintained at $95^{\circ} \mathrm{F}$. for the first 2-3 days and was then gradually reduced until the supplementary heating was turned off completely during the 3 rd week. The room temperature was maintained at about $65^{\circ} \mathrm{F}$. by thermostatically controlled steam radiators. Lighting was provided partly by daylight and partly by tungsten lamps controlled by a time-switch to give $12 \mathrm{hr}$. of light every day.

The birds were kept on wire-mesh floors and the droppings, falling through on to paper-lined metal sheets, were removed two or three times weekly. Food was provided dry and unrestricted in hoppers covered with a light wire mesh to reduce waste by scattering. Water was supplied at the end of each brooder in troughs, which were removed and scrubbed daily.

The brooders were originally designed to house fifty to a hundred chicks on each floor; for experiments where only fifteen to twenty chicks were used in a group, the floors were divided longitudinally by wire-gauze partitions. Until they were 7 days old, the chicks in these subdivided brooders were only allowed half the usual length of the run, to prevent risk of chill. A modified brooder (Pl. I, I) was designed to contain even smaller groups of birds; it had the heated compartment in the middle and half the standard run at each end. When divided throughout its length and width, each floor provided four compartments suitable for groups of ten to fifteen chicks.

For pilot experiments where only two or three chicks could be used at a time, a small constant-temperature room was designed in which birds could be kept in ordinary small-animal cages and the temperature of the room varied according to the age of the birds (Coates, Hall \& Thiel, 1950).

The chicks were usually received on the day of hatching, and all the experiments described here were begun within the first 2 days of life. Deaths occurring during the Ist week on test were not ascribed to the experimental treatment. The birds were weighed and examined for signs of vitamin deficiency twice a week.

Preparation and storage of the diets. It was necessary to disperse very small amounts of potent materials, such as vitamins, evenly throughout all the diets used. A preliminary mixture was made by hand in a mortar by triturating the substance to be dispersed with a small quantity of some finely divided constituent of the diet, such as 
dextrin. 'The contents of the mortar were then added to the rest of the diet and mixed mechanically. For quantities up to $10 \mathrm{~kg}$. a bench model mechanical dough mixer (Hobart Manufacturing Co. I.td.) was used. Larger amounts were mixed in a $200 \mathrm{lb}$. horizontal-paddle mixer ( $\mathrm{Wm}$. Gardner and Sons (Gloucester) Ltd.). Oily substances were best incorporated by pouring them on to a rather granular material like gelatin or casein for mixing with the bulk of the diet. Before mechanical mixing, aqueous solutions were poured on to sufficient dry constituents in a mortar to make a paste suitable for blending.

Refrigerator space was not available for storing large quantities of diet; as it was not considered advisable to keep it at laboratory temperature for much longer than a week, relatively small amounts were made up at about weekly intervals.

Standards. As most of our work was done for the purpose of designing methods of assay and not of determining the absolute vitamin contents of any particular material, commercially pure crystalline vitamins were generally used as standards. For nicotinicacid assays the acid itself was at first used. It was later replaced by nicotinamide, as indicated in the text.

Statistical treatment of results. Results of biological assays were treated by the common-slope technique described by Irwin (1937). The curves of response were tested for linearity and parallelism by variance analysis as described for assays of vitamin $\mathrm{D}_{3}$ by the British Standards Institution (1940). Calculations of potency and limits of error were made as laid down in that publication; the true fiducial limits (T.F.I.) at $P=0.95$ were calculated.

Where it was required to test the significance of differences between two means, 'Student's' (1908, 1925) $t$ test was used, with the level of significance $P=0.95$.

\section{Part 2. The selection of a basal diet}

\section{The production of nicotinic-acid deficiency}

Nicotinic acid was chosen as the first vitamin to be investigated, there being no satisfactory rat test for it, whereas promising results had been obtained by Hegsted (1946) with ducklings.

The basal diet. A diet based on those recommended by Briggs, Mills, Elvehjem \& Ilart (1942) and Luckey, Briggs, Elvehjem \& Hart (1945) was designed; it had the following percentage composition: dextrin (white, maize) 60.45, casein (vitamin-free, Glaxo Laboratories Ltd.) 18, gelatin ('Spa' brand, B. Young and Co. I.td.) 10, salts IV* 5 , calcium acid phosphate $I$, arachis oil 5 , cystine 0.3 , inositol $0 \cdot 1$, choline 0.15 .

To each $100 \mathrm{~g}$. of diet the following vitamins were added: aneurin hydrochloride $300 \mu \mathrm{g}$., riboflavin $600 \mu \mathrm{g}$., calcium pantothenate $1.5 \mathrm{mg}$., pyridoxin $400 \mu \mathrm{g}$., biotin $20 \mu \mathrm{g}$., folic acid $75 \mu \mathrm{g}$., $\alpha$-tocopherol $3 \mathrm{mg}$., 2 methyl-r:4-naphthoquinone $5 \mathrm{mg}$.

'The fat-soluble vitamins were dissolved in the arachis oil, vitamin $A$ being supplied by a fish-liver oil concentrate, and vitamin $\mathrm{D}_{3}$ as crude irradiated 7 -dehydrocholesterol. The stated riboflavin content of the casein was not more than $0.5 \mu \mathrm{g} . / \mathrm{g}$. and we assumed that the other members of the vitamin $B_{2}$ complex were absent, or present only in correspondingly low amounts.

*Hegsted, Mills, Elvehjem \& Hart (194I). 
Sufficient commercial vitamin-free casein was not available to cover all our requirements, and considerable quantities were made in the laboratory from fresh separated milk. The method was based on that of Clark, Zoller, Dahlberg \& Weimar (1920) for the preparation of 'grain curd' casein, but the curd was washed twice with a $2 \%$ solution of sodium chloride at $\mathrm{pH}_{4} \cdot 6$, as recommended by Supplee, Flanigan, Hanford \& Ansbacher (1936) for efficient removal of riboflavin.

Samples of casein made by this method were examined chemically for riboflavin by Dr S. Y. Thompson, and microbiologically for biotin and pantothenic acid by $\mathrm{Mr} F$. Wilby. Negligible amounts were found.

Preparation of liver extracts for inclusion in the diet. In addition to the known vitamins, the diet used by Briggs et al. (1942) contained a liver fraction, and that of Luckey et al. (1945) included a preparation of 'vitamins $B_{10}$ and $B_{11}$ '. When our work was begun the necessity for either of these preparations was open to question, but in view of evidence presented by several workers (Stokstad \& Manning, 1938; Schumacher, Heuser \& Norris, 1940; Briggs, Luckey, Elvehjem \& Hart, 1943) that chicks require hitherto-unidentified members of the vitamin B complex, the need to supply them as a concentrate of some natural material was investigated.

The liver fraction used by Briggs et al. (1942) was that prepared by Hutchings, Bohonos \& Peterson (194I) in work on growth factors for bacteria. Their starting material was a solubilized liver fraction supplied by the Wilson Laboratories, Chicago. It was described as 'that portion of an aqueous liver extract precipitated from solution by addition of ethanol to 70 per cent. concentration, then rendered water-soluble by enzyme action'. No similar preparation could be purchased in this country, and the manufacturers withheld further details of its constitution or preparation. However, Dr T. H. Mead of the British Drug Houses Ltd. kindly prepared the precipitate obtained from an aqueous liver extract when ethanol was added to $70 \%$ concentration. The product was a brown powder, of which $10 \mathrm{~g}$. were equivalent to $45^{\circ} \mathrm{g}$. raw liver, and it was used to prepare in this laboratory a more refined liver fraction, by following as closely as possible the method of Hutchings et al. (194I).

The material ( $\mathrm{rkg}$.) was stirred continuously with rog. papain (British Drug Houses Ltd.) in 201 . distilled water at $\mathrm{pH} 7$ for $24 \mathrm{hr}$. and kept at $55^{\circ}$ in a water-bath. Only about one-third of the solid material was digested in this time. Pilot experiments had shown, however, that not much more could be expected under these conditions; to avoid decomposition of the material if held at $55^{\circ}$ for a longer time, the undigested portion was filtered off, and the filtrate was adjusted to $\mathrm{pH}_{3}$. The precipitate which formed was removed with the aid of Filter Cel (British Drug Houses Ltd.). The filtrate was stirred with $200 \mathrm{~g}$. fuller's earth for $\mathrm{I}$ hr. The fuller's earth was then removed and stirred for $40 \mathrm{~min}$. with $50 \%(\mathrm{v} / \mathrm{v})$ ethanol, filtered off and eluted with 51 ammoniacal ethanol ( 5 vol. absolute ethanol, I vol. conc. ammonia solution, 4 vol. water) at $70^{\circ}$ for I hr. The elution was repeated once, and the combined eluates were evaporated under reduced pressure.

A further similar preparation was made with another $2 \mathrm{~kg}$. of the liver extract. The evaporated eluates were combined, further concentrated at a temperature below $50^{\circ}$ and then dried in a desiccator over phosphorus pentoxide. 
From the $3 \mathrm{~kg}$. of starting material, that is from $\mathrm{I} \mathrm{kg}$. of material actually digested, $65 \mathrm{~g}$. of dried liver fraction were obtained. On the assumption that this represents a $60 \%$ yield (Hutchings et al. I94I), $0.5 \mathrm{~g}$. of this fraction (referred to as L.F. I) was equivalent to $5 \mathrm{~g}$. of the British Drug Houses solubilized product, i.e. to $225 \mathrm{~g}$. raw liver.

In addition, a liver fraction (referred to as L.F. 2) similar to that used by Briggs et al. (1942) was prepared for us by Mr L. K. Parker of Glaxo Laboratories Ltd. The full details of its preparation were not supplied, but it was a crude extract which had been treated to remove nicotinic acid; $2 \cdot 25 \mathrm{ml}$. of it were equivalent to $225 \mathrm{~g}$. of raw liver and therefore to $0.5 \mathrm{~g}$. of L.F. I.

Microbiological tests for nicotinic acid showed that extract L.F. I contained $303 \mu \mathrm{g}$. $/ \mathrm{g}$. and extract L.F. $237 \mu \mathrm{g}$./ml. They were incorporated into the experimental diets at a level equivalent to $225 \mathrm{~g}$. raw liver in $100 \mathrm{~g}$., so that the amount of nicotinic acid contributed by either was negligible.

Response of chicks to the diet with liver extracts. Two groups of twenty chicks were given at 2 days of age the basal diet containing one or other of the liver extracts. 'Two more groups received the same diets supplemented with nicotinamide, $5 \mathrm{mg} / \mathrm{l} / \mathrm{g} \mathrm{g}$. The Olsson diet (Olsson, 194I) supplemented with I \% Ministry of Food veterinary cod-liver oil, and considered, from previous experience in this laboratory, to support normal growth in chicks, was given to a positive control group. The test lasted 3 weeks and the growth of the chicks is shown in Fig. $\mathrm{I}$.

None of the birds given nicotinamide died or showed any adverse signs. 'They gained in weight almost as well as the positive control birds, although their average daily food consumption was slightly less. The droppings of all groups were very liquid, but otherwise the diet seemed satisfactory. The birds given no nicotinamide grew very poorly and ate little. A few died in the 2nd and 3 rd weeks of test, but autopsy revealed no striking abnormalities. In the surviving chicks feathering was poor, comb development retarded and several cases of perosis occurred. Many birds developed a condition of 'parrot beak', in which the beak became shortened and arched (Pl. 2, 1). All had the white tongue tips and red inflamed mouths described by Briggs et al. (1942) as typical of nicotinic-acid deficiency.

Neither liver extract nor its absence affected the responses of the birds to nicotinamide.

Incestigation of the necessity for a liver extract in the diet. The basal diet, supplemented with the liver extracts and with nicotinamide proved almost as good as the positive control diet of natural ingredients. However, the preparation in the laboratory of enough liver extract for incorporation in the diet for routine assays was impracticable, and no such liver extract could be bought commercially. The basal diet was, therefore, tested for its adequacy without liver supplements. 'Two groups of sixteen birds were given the basal diet with and without a nicotinamide supplement of $5.0 \mathrm{mg} . / \mathrm{r} 00 \mathrm{~g}$. and their responses were compared with those of two similar groups given liver extract (L.F. I) as in the previous experiment. As before, a positive control group of birds received the Olsson (194I) diet with I \% cod-liver oil. The test lasted 20 days and the weight responses of the birds are plotted in Fig. 2. The improvement of the basal diet 
by the liver extract was only slight, and the unsupplemented diet was adopted for further tests, though it was recognized that it might be slightly deficient in unidentified growth factors. The growth response of chicks to the basal diet without nicotinamide also is shown in Fig. $3 a$. This response, though greater than that plotted in Fig. 2 is nevertheless well below that to the complete diet.

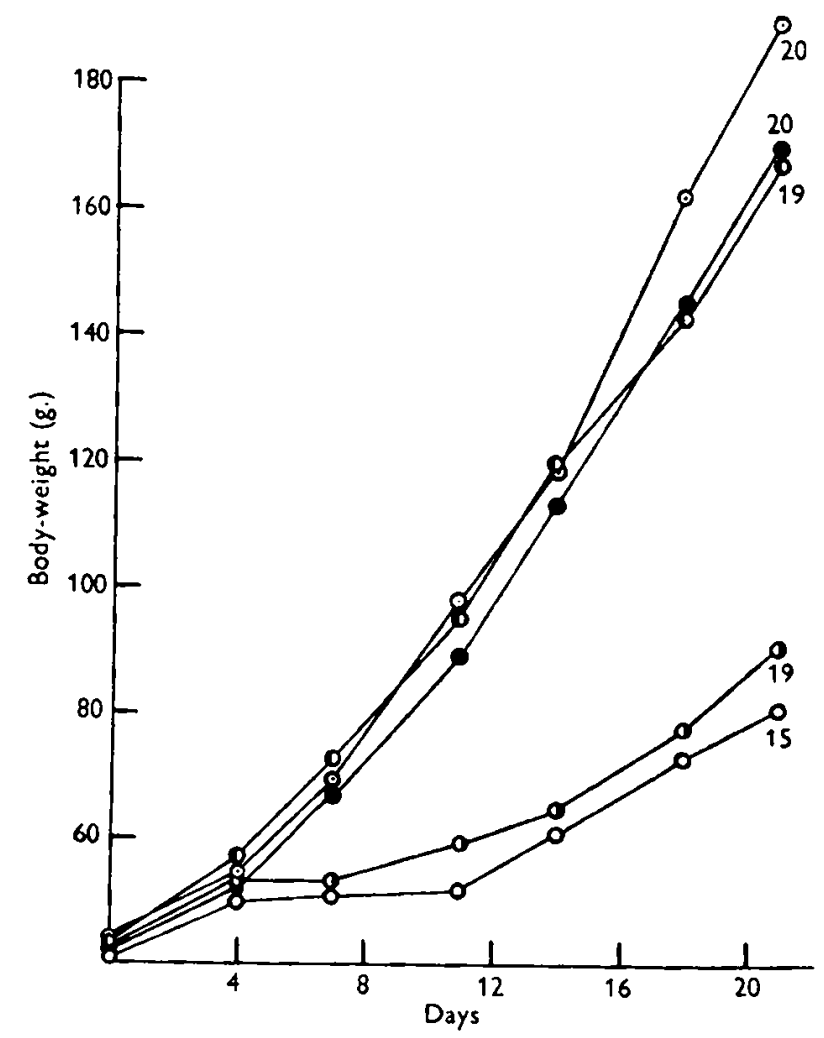

Fig. I. Growth of chicks on diets with or without nicotinamide: $0_{-}-0$, basal diet containing liver fraction $\mathrm{x}$; - , basal diet containing liver fraction $\mathrm{I}$ and $5 \mathrm{mg}$. nicotinamide/100 g.; (1- - basal diet containing liver fraction 2; $\mathrm{C}-\mathrm{C}$, basal diet containing liver fraction 2 and $5 \mathrm{mg}$. nicotinamide/ $100 \mathrm{~g}$; $\odot-\bigcirc$, normal control (Olsson diet). Figures on graph indicate the number of birds contributing to each curve.

Changes in the major constituents of the basal diet. Sources of carbohydrates and protein other than those used in our basal diet have been recommended by some workers. For instance, Sarma et al. (1946) used glucose and blood fibrin, in a diet otherwise similar to ours, for work on the vitamin $B_{6}$ group. Both materials were tried in our basal diet, replacing dextrin and casein, respectively, but no advantage was found in using glucose and very poor results were obtained with blood fibrin. The sample, although a normal commercial one, appeared to contain other blood components besides fibrin. The birds that received it grew poorly, some died, and those that survived till the $4^{\text {th }}$ week gained less than $20 \mathrm{~g}$. throughout. During the 2 nd week on the diet the tongue tips of all birds withered and appeared to drop off, producing a condition of 'blunt tongue', shown in Pl. I, 2,3. A similar tongue deformity 
associated with deficiency of isoleucine was noted by Grau (1945). He reported that the withered tongue tip did not drop off, but became folded back tightly on to the underside, and could be restored to normal if the birds were given isoleucine. Since blood meal is deficient in this amino-acid, whereas blood fibrin is a complete protein for chicks (Grau \& Almquist, 1944), we assumed that the commercial sample of blood

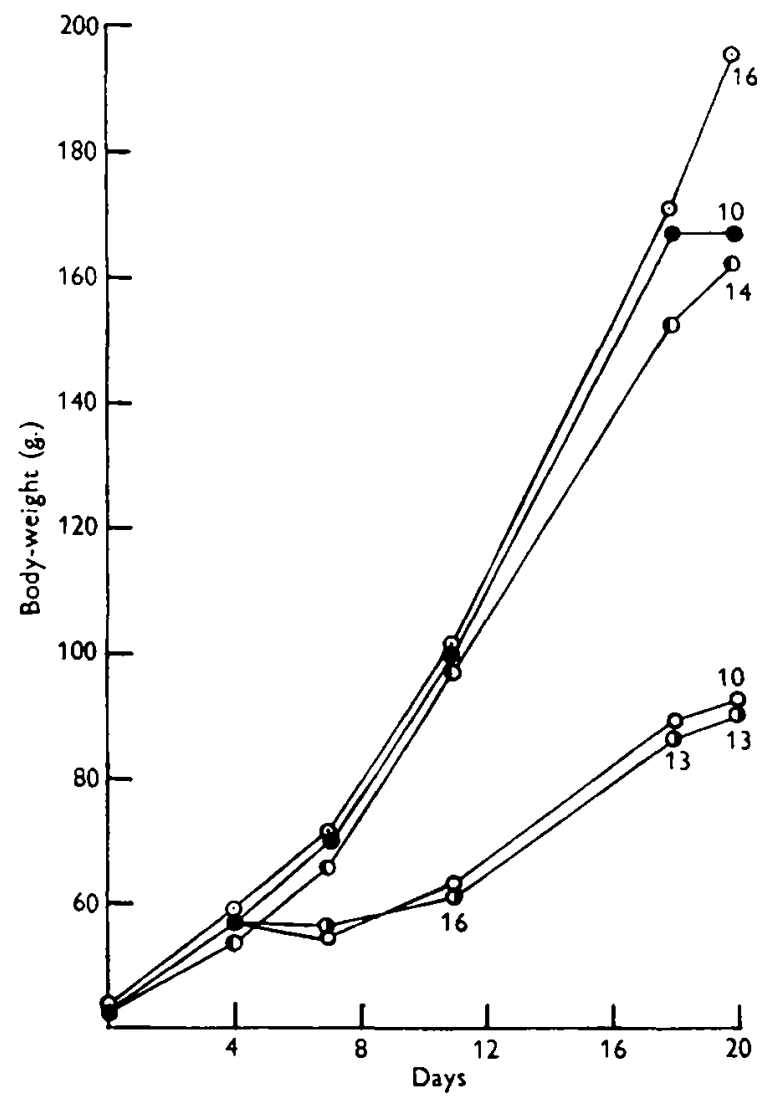

Fig. 2. Growth of chicks with or without nicotinamide and liver extract: $0_{-}-$, basal diet containing liver fraction 1 ; - , basal diet containing liver fraction $I$ and $5 \mathrm{mg}$. nicotinamide/100 g.; $0-\mathcal{O}$, basal diet alone; $\mathbf{C}-\mathbf{C}$, basal dict containing $5 \mathrm{mg}$. nicotinamide/100 g.; $\odot-\odot$, normal control (Olsson diet). Figures on graph indicate the number of birds contributing to each point or curve.

fibrin was in reality blood meal, and therefore unsuitable as the main protein source in the diet. A sample of genuine blood fibrin prepared in the laboratory supported normal growth in chicks, even in the absence of nicotinic acid, and was, therefore, equally unsuitable.

Examination of the suitability of the basal diet for production of other vitamin deficiencies.

The basal diet, having proved suitable for the production of nicotinic-acid deficiency, was next tried for its usefulness in producing other deficiencies by omitting in turn one of each of the other vitamins. 
Groups of sixteen birds were given the deficient diets from hatching. Nicotinamide $(5 \mathrm{mg} / 100 \mathrm{~g}$.) was included in all the diets, and as a positive control the basal diet with the complete vitamin supplement was given.
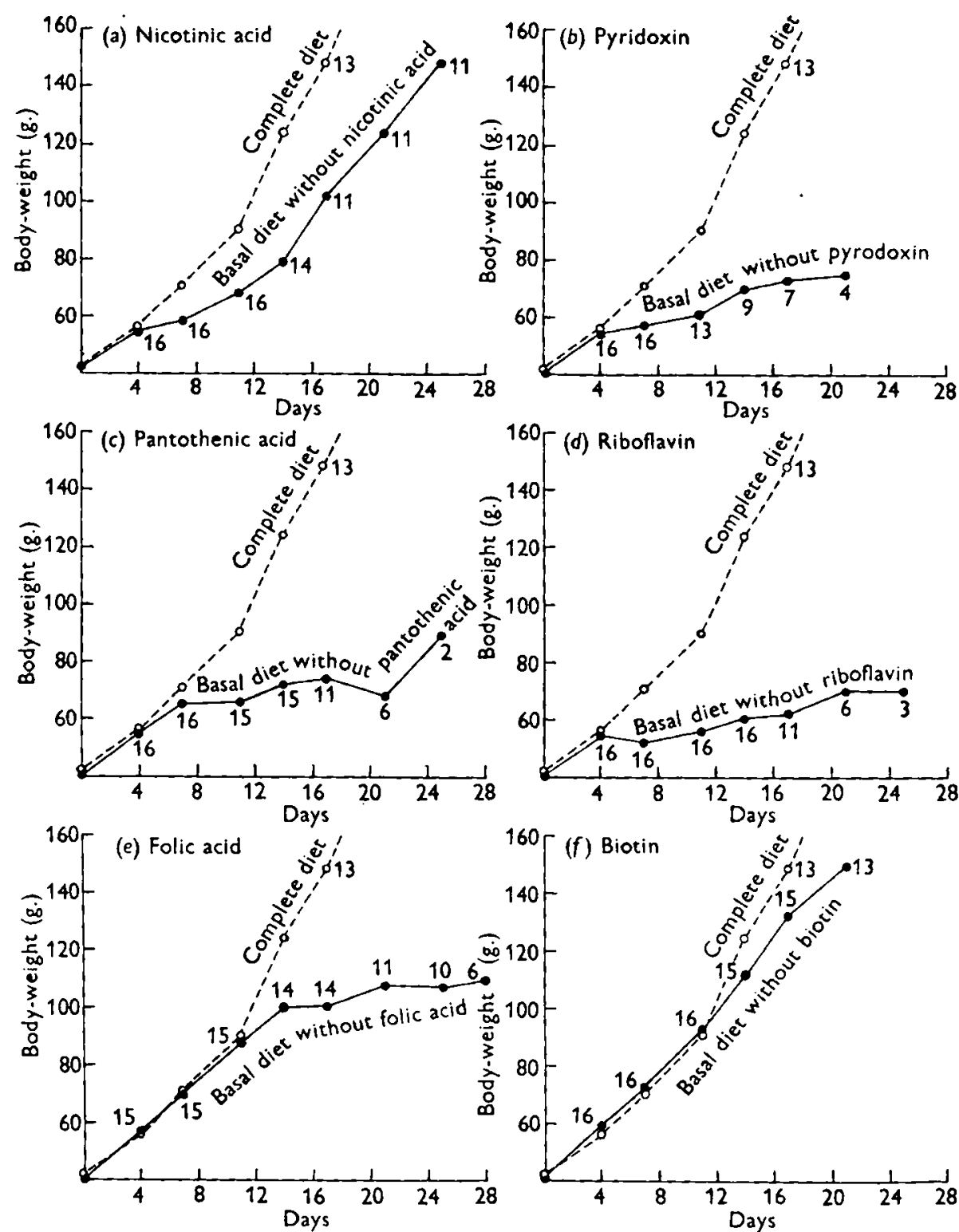

Fig. 3. Growth of chicks on six different diets, each deficient in one vitamin of the $B$ complex. Figures on graph indicate the number of birds contributing to each point/or curve.

In each of the vitamin deficiencies studied, a specific syndrome was observed.

Pyridoxin. A very marked depression of growth occurred (Fig. $3^{b}$ and Pl. 2, 2). The other signs were mainly nervous in character and began to appear in the $2 n d$ week of the experiment. The chicks became extremely excitable and restless and ran wildly 
up and down the brooder when disturbed, after which followed fits of vertigo and tremors, and in more severe cases convulsions, usually resulting in death. The deaths began on the gth day and only three birds survived until the 21st day of test. A similar syndrome of pyridoxin deficiency has been described by Lepkovsky \& Kratzer (1942). Post-mortem examination showed in most birds enlarged gall-bladders and occasionally pale livers and spleens.

Pantothenic acid. A depression of growth was noted (Fig. 3.c), though not quite as severe as in pyridoxin deficiency. The most distinctive sign was the appearance of dermatitis round the beak. It began as a slight encrustation at the corners of the mouth, later developing into definite lesions ( $\mathrm{Pl} .2,3)$; by the end of the and week of test all the birds were affected. About the same time, the eyelids of some birds became closed by a sticky exudate, but could be separated, especially if bathed. Similar signs have been described by Jukes (1947). Many birds died towards the end of the $3^{\text {rd }}$ week, and only one was still alive on the 27 th day of test. Post-mortem examination showed enlarged gall-bladders, and occasionally dark and patchy livers. An abnormally large amount of unabsorbed yolk sac was noticed in the birds that died earlier in the experiment.

Riboflavin. The typical 'curled-toe' paralysis of riboflavin deficiency was observed in only one bird $(\mathrm{Pl} .2,4)$. However, the chicks grew very poorly (Fig. $3^{d}$ ), the average gain being only about ro g./week. Norris, Wilgus, Ringrose, Heiman \& Heuser (1936) reported that curled-toe paralysis occurs more frequently in chicks given small quantities of riboflavin than in birds completely deprived of it, and we confirmed this later in our investigation (see p. 218). A few birds developed rather 'knobbly' feet, a condition later found to precede curled-toe paralysis.

During the $3^{\text {rd }}$ week of test the birds developed diarrhoea. Deaths began on the $15^{\text {th }}$ day and no bird survived beyond the $27^{\text {th }}$ day. Post-mortem examination showed enlarged gall-bladders and very yellow livers.

Folic acid. The birds appeared normal until after the 2nd week of test, when the growth rate declined (Fig. $3 e$ ), the combs and mouthparts appearing extremely pale. Feathering was poor and the wing feathers became brittle and ragged (Pl. 2, 5). Birds began to die during the $3^{\text {rd }}$ wcek, but six survived to the end of the experiment. Post-mortem examination showed no marked changes except extreme pallor of the organs. Two cases of perosis were observed.

A further experiment was done using glucose or sucrose in the diet instead of dextrin, which might have promoted intestinal synthesis. The growth rates and general condition of the chicks were very similar to those just described. Haemoglobin measurements and erythrocyte counts were made on the blood of some of the chicks and both values were considerably lower than normal. It seemed possible that they might form a more specific and sensitive criterion of response for an assay than growth, and in later experiments $\mathrm{Hb}$ levels were taken as a measure of response (see p. 215).

Biotin. The general condition of the birds was good during the first 2 weeks, and only four deaths occurred during the whole 4-week period of test. After the 2 nd week several signs of deficiency appeared. Three cases of perosis were observed, and withered tongue tips occurred frequently. Most birds developed 'parrot beak' and the beak 
became softened and wavy so that the two mandibles did not meet when closed. 'The skin of the feet became very scaly, particularly on the underside, and deep cracks developed from which bleeding occurred (P1. 2, 6). The growth rate throughout the 4 weeks of test was very little different from that of normal birds (Fig. $3 f$ ), and was therefore useless as a measure of biotin deficiency. The lack of effect on growth might have been due to some intestinal synthesis of biotin supported by dextrin, so other groups of birds were given glucose or sucrose instead. The response was very little different and attempts to devise an assay for biotin were abandoned for the time being.

\section{Nicotinic acid}

\section{Part 3. The construction of dose-response curves}

Method. Details of technique were first worked out for nicotinic acid. Groups of sixteen birds were given the basal diet with graded doses of nicotinamide of $0.5,1,2,3$, 4 and $5 \mathrm{mg} / \mathrm{roo}$ g. diet. A seventh group received the basal diet with no added nicotinamide. The expected signs of nicotinic-acid deficiency, red mouthparts and white tongue tips, poor feathering and 'parrot beak', appeared among birds in the lower dose groups.

Statistical treatment. Growth curves were plotted and a maximal response was obtained at the $4 \mathrm{mg}$. level. At the 18 th day a linear response (Fig. $4 a$ ) was obtained with the lower five levels when body-weight was plotted against the logarithm of the dose.

The slope $(b)$ of the line was $47 \cdot 61$, with an error $\left(s_{b}\right)$ of $6 \cdot 93$. The ratio $b: s_{b}$ was 6.87 .

These results suggested that a dose-response curve suitable for biological assay could be obtained for nicotinic acid, with dose levels of nicotinamide between 0.5 and $4 \mathrm{mg} . / 100 \mathrm{~g}$. diet, in a test of about 3 weeks' duration.

\section{Pyridoxin}

Method. A procedure similar to that with nicotinic acid was followed, the basal diet containing no added pyridoxin. The pyridoxin supplements were 20,40 and $80 \mu \mathrm{g} . / \mathrm{r} 00 \mathrm{~g}$. diet and groups of twelve chicks were used. The nervous signs already described (p. 2 I I) appeared at a very early stage in the birds given less than $80 \mu \mathrm{g} . / \mathrm{roog}$. Although the experiment was continued for 3 weeks, a large proportion of the birds on the lowest dose died earlier, so that it was considered complete after 14 days.

Statistical treatment. When body-weight on the $14^{\text {th }}$ day was plotted against the logarithm of the dose, a straight line was obtained (Fig. 4 b). Its slope was 84.69 with an error of 7.54 and the ratio $b: s_{b}$ was $11 \cdot 2$. Maximal response was not obtained, but the results suggested that it would probably be produced by a concentration of pyridoxin of about $100 \mu \mathrm{g}$./100 g.

The very high ratio of $b: s_{b}$ suggested that an accurate assay could be designed for pyridoxin by using the basal diet supplemented with doses of pyridoxin between 20 and $100 \mu \mathrm{g}$. $/ 100 \mathrm{~g}$. and that the rapid onset of signs of deficiency would make it possible to obtain results within 14 days. 


\section{Pantothenic acid}

Method. Only a pilot experiment was done. Groups of four chicks received calcium pantothenate at the rate of $0.125,0.25,0.5$ and $\mathrm{r} \cdot 0 \mathrm{mg} / \mathrm{r} 00 \mathrm{~g}$. diet. A fifth group received the basal diet alone.
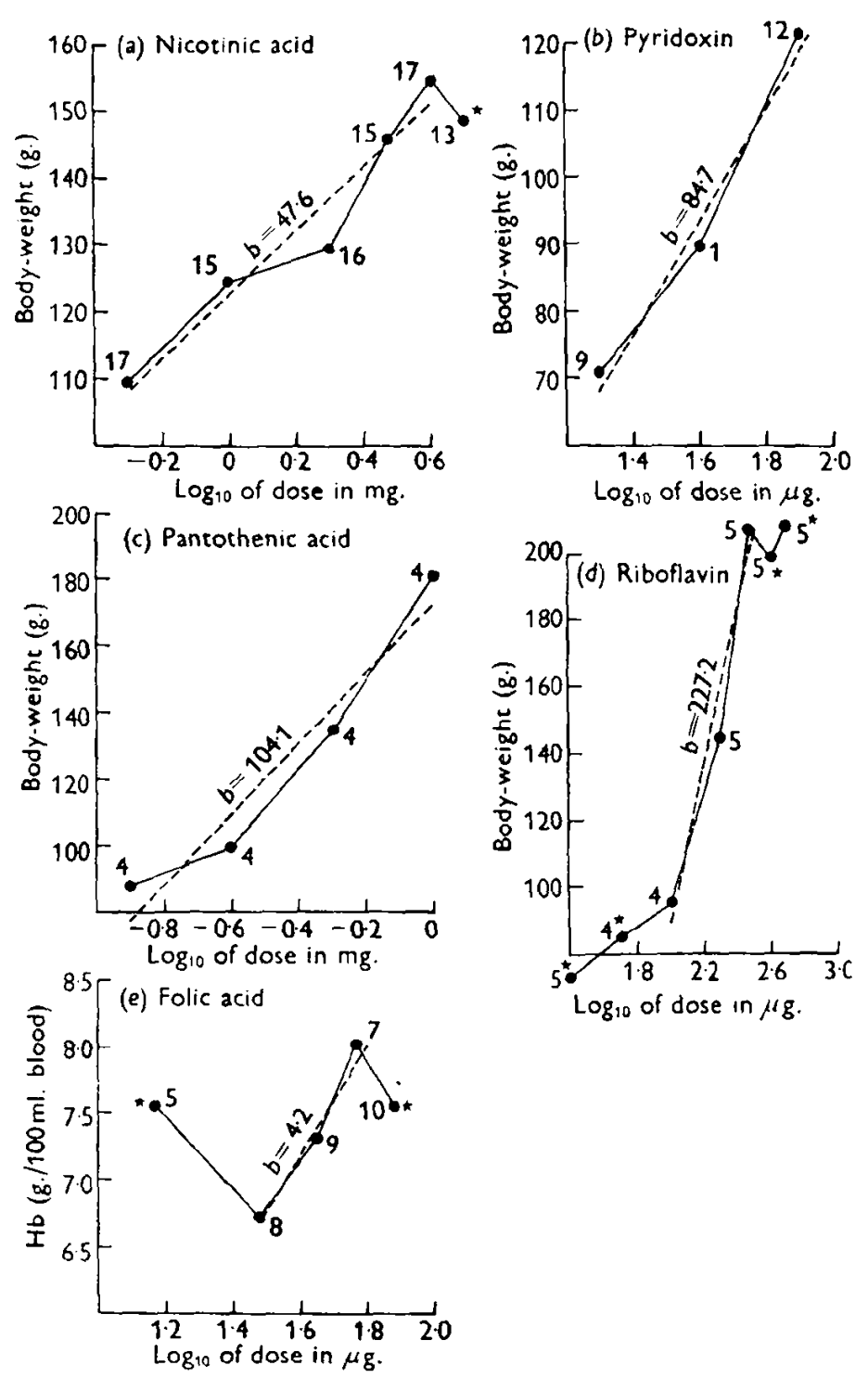

Fig. 4. Dose-response curves for five vitamins of the vitamin B complex. Figures on graph indicate the number of birds contributing to each point; $\bullet$ indicates points that were non-linear.

Satisfactory growth was maintained at the highest dose, but even that may not have been maximal. All the birds survived the test period of 28 days, and the typical mouth lesions and closed eyelids already described (p. 212) were observed among those on the lower doses. 
Statistical treatment. After 3 weeks on the diet, the curve representing the mean body-weights for all four doses plotted against the logarithm of the dose easily passed the test for linearity (Fig. 4 c). 'I'he slope of $104 \cdot \mathrm{I}$ had a high error $\left(s_{b}=22.9\right)$, so that the ratio $b: s_{b}$ was only $4 \cdot 55$. The accuracy would almost certainly have been greater if the number of birds in each group had been sufficiently increased. The findings indicated that groups of twelve to sixteen birds would be necessary in a full-scale assay, which could be carried out between the doses of 0.25 and (at least) I mg./100 g. diet.

\section{Riboflavin}

Method. Although the methods of assay available for riboflavin, either chemical or microbiological, or by the rat-growth test, are satisfactory, it was considered advisable to develop a method with chicks as well.

A small-scale experiment only was carried out, with five birds on each dose. The riboflavin supplements were $25,50,100,200,300,400$ and $500 \mu \mathrm{g}$. riboflavin/roo g. diet. An eighth group received the basal diet without riboflavin. Maximal response was obtained with $300 \mu \mathrm{g}$. Mortality was very low, and only one or two birds on the lowest dose died during the 4-week experiment. Curled-toe paralysis was noted in some of the birds on low doses of riboflavin, but not in any receiving the basal diet alone.

Statistical treatment. Only at three levels, those of 100,200 and $300 \mu \mathrm{g} / \mathrm{r} 00 \mathrm{~g}$. was the test for linearity satisfied when body-weight on the $24^{\text {th }}$ day was plotted against the logarithm of the dose. The resulting line (Fig. $4 d$ ) had a slope of $227 \cdot 2$, with an error of $38 \cdot 4 ; b: s_{b}$ was therefore $5 \cdot 92$.

\section{Folic acid}

Method. Groups of ten birds were given the basal diet supplemented with 15, 30, 45,60 or $75 \mu \mathrm{g}$. folic acid/100 g. diet. A sixth group received the basal diet alone. By the beginning of the $4^{\text {th }}$ week on diet the birds on the lower doses began to look very anaemic and on the 26th day $0.05 \mathrm{ml}$. blood was taken from the wing vein of each chick into dilute ammonium hydroxide (the concentrated solution diluted $\mathrm{I}: 250$ ). It was difficult to get freely flowing blood from the very small birds, so that in one or two cases of extreme deficiency no sample was obtained. $\mathrm{Hb}$ was determined in the samples by a modification of the oxyhaemoglobin technique.

Statistical treatment. The dose-response curve obtained by plotting the mean $\mathrm{Hb}$ values in $\mathrm{g} . / 100 \mathrm{ml}$. against the logarithm of the dose is presented in Fig. $4 e$.

The responses to the lowest and highest doses were very far out of line with the rest, but a straight line could be calculated through the responses to the middle three doses. Its slope was 4.214 and, although it easily passed the test for linearity, its error was 2.455 . This gave the extremely low value of $1 \cdot 72$ for the ratio of $b: s_{b}$. This error was large mainly because of the considerable variation between the birds at each dose level. Although matters might have been improved by increasing the size of the groups, the time necessary to take blood samples from each bird and determine the $\mathrm{Hb}$ content limits the number that can be dealt with in one day.

\section{Statistical data}

The statistical data for the dose-response curves are summarized in Table 1. 
'Iable $\mathrm{x}$. Relation between response of chick and logarithm of dose for five vitamins of the $B$ complex

\begin{tabular}{|c|c|c|c|c|c|c|}
\hline Vitamin & $\begin{array}{l}\text { Variable } \\
\text { measured }\end{array}$ & $\begin{array}{l}\text { Range of dose } \\
\text { ( } \mu \mathrm{g} . / 100 \mathrm{~g} . \\
\text { diet) }\end{array}$ & $\begin{array}{l}\text { Slope } \\
(b)\end{array}$ & $\begin{array}{l}\text { Standard } \\
\text { error of } \\
\text { slope } \\
\left(s_{b}\right)\end{array}$ & $\begin{array}{c}\text { Variance } \\
\text { ratio }\end{array}$ & $\begin{array}{l}5 \% \text { point } \\
\text { of variance } \\
\text { ratio }\end{array}$ \\
\hline Nicotinamide & Body-weight & $500-4000$ & $47 \cdot 61$ & $6 \cdot 93$ & 0.58 & $\begin{array}{l}2 \cdot 74 \\
4 \cdot 17\end{array}$ \\
\hline $\begin{array}{l}\text { Pyridoxin } \\
\text { Calcium pantothenate }\end{array}$ & $\begin{array}{l}\text { Body-weight } \\
\text { Body-weight }\end{array}$ & $\begin{array}{r}20-80 \\
125-1000\end{array}$ & $\begin{array}{r}84 \cdot 69 \\
84 \cdot 1\end{array}$ & $\begin{array}{r}7 \cdot 54 \\
22 \cdot 0\end{array}$ & $\begin{array}{l}3.02 \\
0.63\end{array}$ & $\begin{array}{l}4.17 \\
3.88\end{array}$ \\
\hline Riboflavin & Body-weight & $100-300$ & $227 \cdot 2$ & $38 \cdot 4$ & $1 \cdot 86$ & 4.54 \\
\hline Folic acid & Hb content of blood & $30-60$ & 4.214 & $2 \cdot 455$ & 0.08 & $4 \cdot 32$ \\
\hline
\end{tabular}

Part 4. Assays of pure substances

The validity of the methods just described was tested by using them for measuring the concentration in preparations of the pure substances of the five vitamins studied. Samples for test were prepared for us, only the rough order of potency being disclosed before the test.

\section{Nicotinamide}

\section{Arrangement:}

Test matcrial

Assumed potency of test solution

No. of birds/group

Doses: standard test solution

Duration of test
A solution in water $4 \mathrm{mg} . / \mathrm{ml}$.

20

$0.5, \mathrm{r} \cdot 0,2.0$ and $4.0 \mathrm{mg} / \mathrm{r} 00 \mathrm{~g}$. diet. $0.125,0.25,0.5$ and $1.0 \mathrm{ml} . / 100 \mathrm{~g}$. diet 21 days

Most birds survived the entire period of test and marked symptoms of nicotinicacid deficiency were noted among those on the lower doses.

Statistical treatment. Throughout the test, the performance of birds given the highest dose of standard was poorer than expected, and in the final calculation this group had to be discarded as the response was not linear with that of the other groups. No explanation could be found for the poor response, for the initial weights of the birds in this group did not differ significantly from those in the remaining groups. When the response to the four doses of the test substance was calculated against that to the lower three doses of standard (Fig. 5a), the lines of response proved straight and parallel, and the content of the nicotinamide solution was calculated as $3.64 \mathrm{mg} . / \mathrm{ml}$. with true fiducial limits at $P=0.95$ of 2.79 and $4.86 \mathrm{mg}$. $/ \mathrm{ml}$. 'I 'he true content was $3.44 \mathrm{mg}$. $/ \mathrm{ml}$.

\section{Pyridoxin hydrochloride}

\section{Arrangement:}

Test material

Assumed potency of test solution

No. of birds/group

Doses: standard test solution

Duration of test
A solution in water I $60 \mu \mathrm{g} . / \mathrm{ml}$.

19

$20,40,80$ and $160 \mu \mathrm{g} . / 100 \mathrm{~g}$. diet $0.125,0.25,0.5$ and $\mathrm{I} .0 \mathrm{ml} . / \mathrm{r} 00 \mathrm{~g}$. diet 14 days 
The expected symptoms of deficiency were observed among birds on the lower doses. Mortality was high on the lowest doses of both standard and test during the last few days of the experiment.
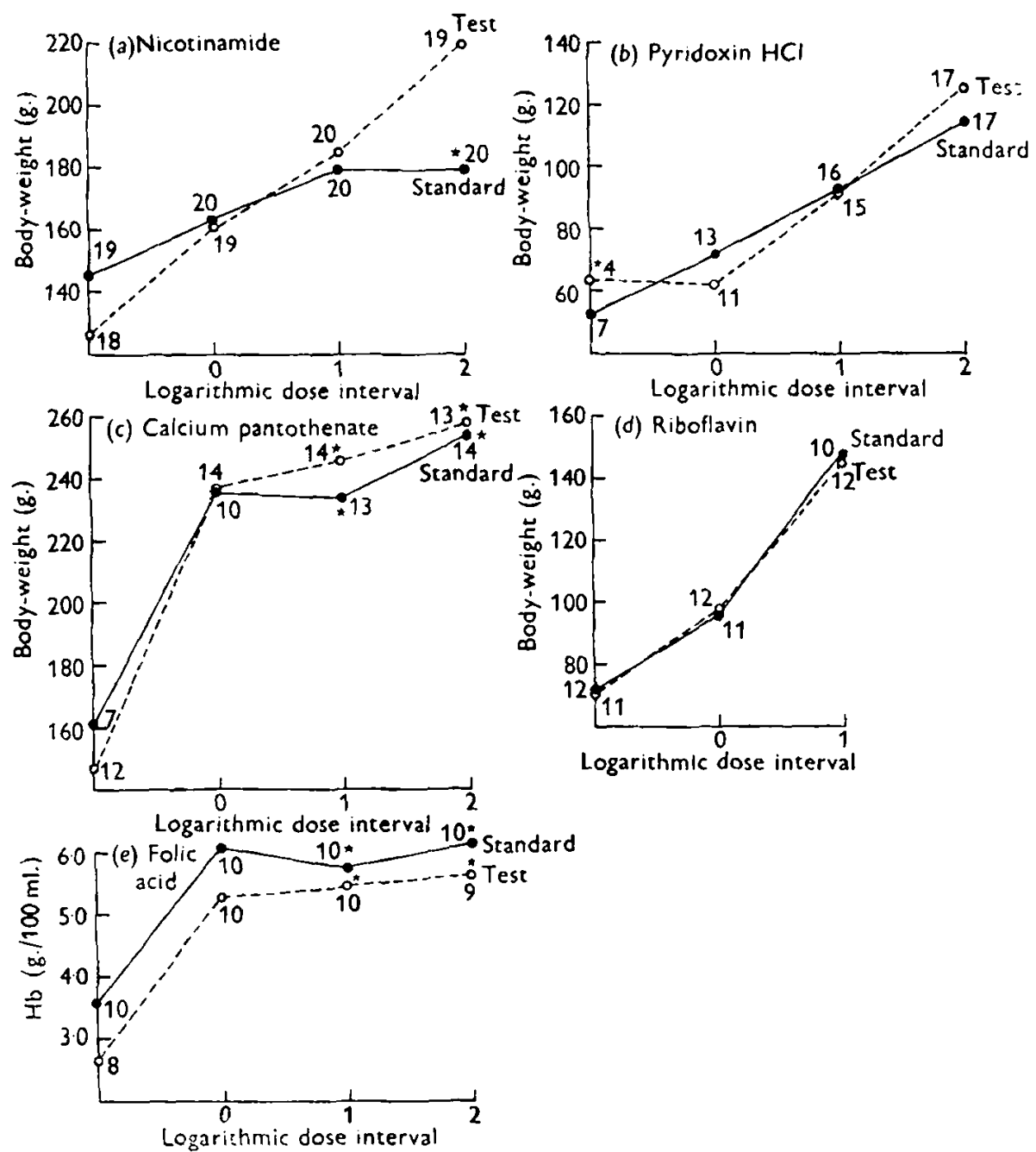

Fig. 5. Assays of dilutions of crystalline preparations of five vitamins of the $B$ complex. Figures on graph indicate the number of birds contributing to each point; " indicates that thel point was omitted from the calculation.

Statistical treatment. As only four birds remained alive on the lowest dose of test solution, it was omitted from the calculation. The responses to the other three doses proved linear with those to the four doses of standard (Fig. $5 b$ ) and the calculated potency was $163 \mu \mathrm{g} . / \mathrm{ml}$., with true fiducial limits at $P=0.95$ of 132 and $205 \mu \mathrm{g} . / \mathrm{ml}$. The true strength of the solution was $160 \mu \mathrm{g} . / \mathrm{ml}$. 


\section{Pantothenic acid}

\section{Arrangement:}

Test material

Assumed potency of the sample

No. of birds/group

Doses: standard

test solution

Duration of test

A solution in water

$\mathrm{r} \cdot 35 \mathrm{mg} . / \mathrm{ml}$.

20

$0.4,0.6,0.9$ and $\mathrm{r} 35 \mathrm{mg}$. calcium pantothenate/ $100 \mathrm{~g}$. diet

$0.30,0.44,0.67$ and $\mathrm{r} \cdot 0 \mathrm{ml} . / \mathrm{r} 00 \mathrm{~g}$. diet

21 days

In view of the result obtained when the dose-response curve was constructed for pantothenic acid (see p. 214), it appeared that a smaller dose ratio than the usual $2:$ I would be suitable and a $\mathrm{I} \cdot 5: \mathrm{I}$ ratio was tried.

Statistical treatment. Near-maximal response was reached with the second lowest dose (Fig. 5 c) and calculation could only be made with the two lowest doses. The result was $\mathrm{I} \cdot 32 \mathrm{mg} . / \mathrm{ml}$, with true fiducial limits at $P=0.95$ of $I \cdot I 7$ and $I \cdot 49 \mathrm{mg} . / \mathrm{ml}$. The true potency of the test solution was $\mathrm{I} \cdot 4 \mathrm{I} \mathrm{mg} . / \mathrm{ml}$.

\section{Riboflavin}

\section{Arrangement:}

Test material

Assumed potency of the sample

No. of birds/group

Doses: standard test powder

Duration of test

\section{A dilution in dextrose}

$560 \mu \mathrm{g} \cdot / \mathrm{g}$.

12

70, I 40 and $280 \mu \mathrm{g} . / 100 \mathrm{~g}$. diet

$0.125,0.25$ and $0.5 \mathrm{~g} .100 \mathrm{~g}$. diet

17 days

Most of the birds survived the whole period of the test. A few cases of curled-toe paralysis, preceded by the 'knobbly feet' described earlier, were observed.

Statistical treatment. The response to test and standard (Fig. $5^{d}$ ) at all three levels passed the test for linearity and parallelism, and the calculated potency was $557 \mu \mathrm{g} . \mathrm{g}$. of test material, with true fiducial limits at $P=0.95$ of 487 and $638 \mu \mathrm{g} . / \mathrm{g}$. The true potency was $500 \mu \mathrm{g} / \mathrm{g}$.

\section{Folic acid}

Arrangement:

'Test material

Assumed potency of the sample

No. of birds/group

Doses: standard test solution

Duration of test

A solution in water I $20 \mu \mathrm{g} . / \mathrm{ml}$.

IO

I $5,30,60$ and $\mathrm{r} 20 \mu \mathrm{g} . / \mathrm{r} 00 \mathrm{~g}$. diet $0.125,0.25,0.5$ and $1.0 \mathrm{ml} . / 100 \mathrm{~g}$. diet 25 days

$\mathrm{Hb}$ levels were first measured on the $25^{\text {th }}$ day. The birds were kept until the 32 nd day and the $\mathrm{Hb}$ was measured again, but the values were very little different from those 
found on the 25th day; as most of the birds in the lowest groups were by then in a moribund condition, the first set of values was used.

The maximal response was unexpectedly low and was reached at the $30 \mu \mathrm{g}$. dose. The normal $\mathrm{Hb}$ content for chicks of this age is about $9 \mathrm{~g} . / 100 \mathrm{ml}$., whereas in the present test the highest value was about $6 \mathrm{~g} / 100 \mathrm{ml}$. Such a figure is unlikely to have been due to an analytical error, as a few samples of normal human blood were analysed at the same time and gave the expected results. It is possible that the birds lacked some other factor necessary for the proper utilization of folic acid, although no such suggestion had been noticed in earlier work.

Statistical treatment. The lines through the lower two doses of both standard and test were parallel (Fig. $5 e$ ), and the potency of the test solution was calculated as $103 \mu \mathrm{g} . / \mathrm{ml}$., with true fiducial limits at $P=0.95$ of 86 and $12 \mathrm{I} \mu \mathrm{g} . / \mathrm{ml}$. Its true strength, $120 \mu \mathrm{g} . / \mathrm{ml}$., fell just inside this range.

\section{Statistical data}

The statistical analyses for all these assays are given in Table 2.

Table 2. Assays of preparations of pure vitamins: results obtained compared with true, but at the time undisclosed, potency

\begin{tabular}{|c|c|c|c|c|c|c|}
\hline \multirow[b]{2}{*}{ Vitamin } & \multicolumn{2}{|c|}{$\begin{array}{l}\text { No. of } \\
\text { groups }\end{array}$} & \multirow{2}{*}{$\begin{array}{l}\text { No. of } \\
\text { birds/ } \\
\text { group }\end{array}$} & \multirow{2}{*}{$\begin{array}{l}\text { Potency } \\
\text { found }\end{array}$} & \multirow{2}{*}{$\begin{array}{c}\text { True fiducial } \\
\text { limits at } \\
P=0.95\end{array}$} & \multirow{2}{*}{$\begin{array}{l}\text { True } \\
\text { potency }\end{array}$} \\
\hline & Standard & Test & & & & \\
\hline $\begin{array}{l}\text { Nicotinamide } \\
\text { Pyridoxin hydrochloride }\end{array}$ & $\begin{array}{l}3 \\
4\end{array}$ & 4 & $\begin{array}{l}20 \\
10\end{array}$ & $\begin{array}{l}3.64 \mathrm{mg} / \mathrm{ml} . \\
163 \mu \mathrm{g} . / \mathrm{ml}\end{array}$ & $\begin{array}{l}2.79-4.86 \mathrm{mg} . / \mathrm{ml} . \\
132-205 \mu \mathrm{g} . / \mathrm{ml} .\end{array}$ & $\begin{array}{l}3.44 \mathrm{mg} / \mathrm{ml} \text {. } \\
160 \mu \mathrm{g} . / \mathrm{ml} \text {. }\end{array}$ \\
\hline Calcium pantothenate & $\begin{array}{l}4 \\
2\end{array}$ & $\begin{array}{l}3 \\
2\end{array}$ & $\begin{array}{l}19 \\
14\end{array}$ & $\mathrm{r} \cdot 32 \mathrm{mg} . / \mathrm{ml}$. & $1.17-1.49 \mathrm{mg} . / \mathrm{ml}$. & $1.4 \mathrm{Ig} . / \mathrm{ml}$. \\
\hline Riboflavin & 3 & 3 & 12 & $557 \mu \mathrm{g} . / \mathrm{g}$ & $487-638 \mu \mathrm{g} . / \mathrm{g}$ & $500 \mu \mathrm{g} . / \mathrm{g}$ \\
\hline Folic acid & 2 & 2 & 10 & $103 \mu \mathrm{g} . / \mathrm{ml}$. & 86-121 $\mu \mathrm{g} . / \mathrm{ml}$ & $120 \mu \mathrm{g} . / \mathrm{m}$ \\
\hline
\end{tabular}

Part 5. Effect of granulation of the diet on the dose-response curve

It was noticed in the course of other work in this laboratory that young chicks grew better on 'synthetic' diets if these were given in granular form, rather than as powder.

An assay of a solution of nicotinamide was done in duplicate, once with the diet in its usual form and once with the diet granulated.

Preparation of the granulated diet. The diet was mixed in the usual way, and then tap water, about one-fifth to one-third of the weight, was added. The water was dispersed by prolonged mechanical mixing or preferably by rubbing it in by hand. When the diet had been evenly damped, it was pressed through a no. 8 brass sieve and the granules so formed were spread on stainless steel trays and dried overnight at about $40^{\circ}$.

The dose-response curves obtained with the two types of diet are shown in Fig. 6, and the details of each assay are given in tabular form on p. 220.

It will be seen that a considerably better result was obtained with the granulated diet. The response was linear over a greater range of doses, the slope was steeper, its error less and as a consequence the true fiducial limits were reduced. The figure obtained with the granulated diet was much nearer the true one. This assay may be compared 
with that reported in 'Table 2 with a powdery diet. Although the result obtained there was near the true potency, the limits of error were very wide.

\begin{tabular}{lcc} 
& $\begin{array}{c}\text { Granulated } \\
\text { diet }\end{array}$ & $\begin{array}{c}\text { Powdery } \\
\text { diet }\end{array}$ \\
Slope $(b)$ & $54 \cdot 70$ & $42 \cdot 11$ \\
$s_{b}$ & $2 \cdot 57$ & $4 \cdot 36$ \\
$b: s_{b}$ & $21 \cdot 28$ & $9 \cdot 66$ \\
Calculated potency & $3 \cdot 69 \mathrm{mg} . / \mathrm{ml}$. & $2 \cdot 39 \mathrm{mg} / \mathrm{ml}$. \\
T.F.L. & $3 \cdot 19-4 \cdot 26 \mathrm{mg} . / \mathrm{ml}$. & $1 \cdot 90-3 \cdot 06 \mathrm{mg} / \mathrm{ml}$. \\
& $(86.5-115 \cdot 4 \%)$ & $(79 \cdot 4-128 \cdot 0 \%)$ \\
True potency & \multicolumn{2}{c}{$4 \cdot 2 \mathrm{mg} . / \mathrm{ml}}$.
\end{tabular}

The effect of granulation was next tried in the determination of pyridoxin and pantothenic acid. Dose-response curves were constructed for each using both powdery and granulated diets.

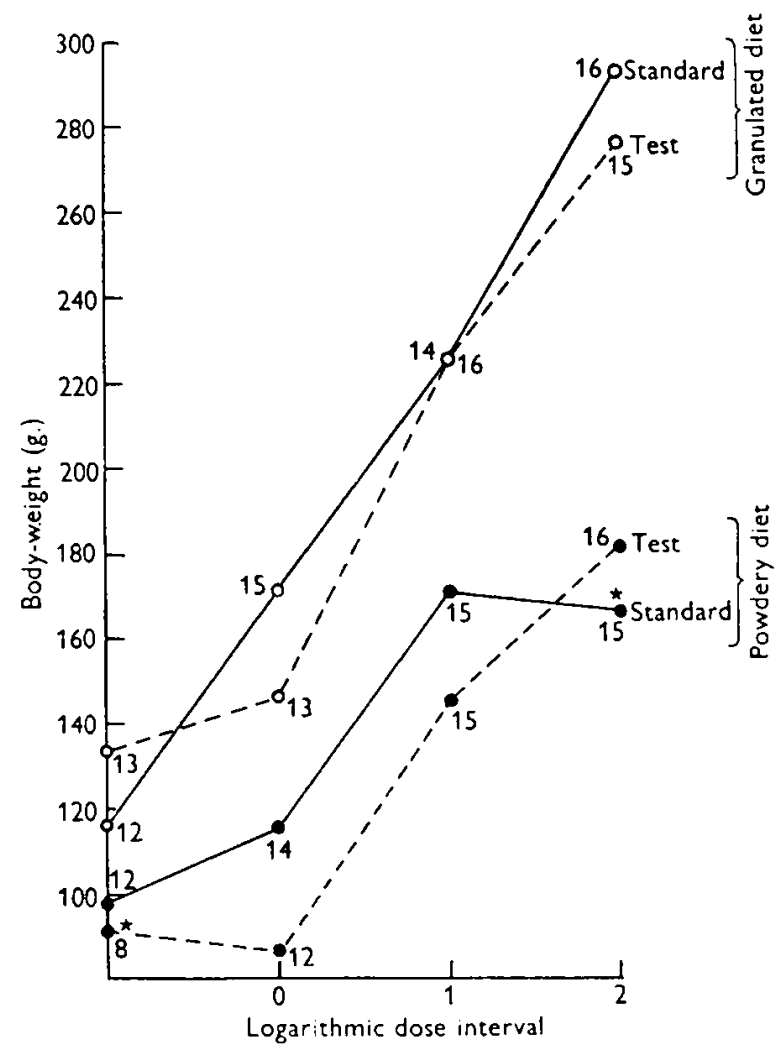

Fig. 6. Effect of granulation of the diet on the dose-response curve in an assay of a solution of nicotinamide. Figures on graph indicate the number of birds contributing to each point; * indicates that the point was omitted from the calculation.

With pantothenic acid the slope, $b$, and the ratio $b: s_{b}$ were increased by granulation to almost three times their value with the powdery diets. With pyridoxin, although the slope itself was not improved, there was an increase in the range over which the response was linear. 
When granulated diets containing doses of folic acid ranging from to to $50 \mu \mathrm{g} . / \mathrm{ro0} \mathrm{g}$. were given to groups of ten chicks, symptoms of anaemia developed much earlier than had been observed with powdery diets. Hb determinations were made on the 18 th day, and the dose-response curve proved linear over the whole range of doses. 'The slope $b$ was $6 \cdot 48$, with an error of $0 \cdot 575$, giving the high value of $11 \cdot 26$ for the ratio of $b: s_{b}$. Further $\mathrm{Hb}$ measurements were made on the 24 th and 28 th days of test, but by then a number of the more deficient chicks in the lower dose groups had died so that the results were less satisfactory. The powdery diet was not examined simultaneously but the steep slope and low error of this dose-response curve compare very favourably with those previously reported with a powdery diet (p. 218). Furthermore, a suitable state of deficiency was obtained in less than 3 weeks, a considerably shorter time than was needed with the powdery diet.

\section{DISCUSSION}

The experiments reported here showed that chicks can be successfully used for the quantitative biological determination of members of the vitamin B complex. They grew well on synthetic diets, especially those given in granular form, and rapidly developed deficiency syndromes characteristic of each of the vitamins studied. The variance among the birds was not unduly large, especially in assays of pyridoxin and riboflavin, and a reasonable degree of precision was obtained in all assays with groups of less than twenty birds.

Nicotinic acid, pyridoxin, riboflavin and pantothenic acid were measured by using change in body-weight as the criterion of response, and folic acid by using change in haemoglobin level. The present paper has dealt only with the measurement of pure vitamins, and for them the methods devised proved entirely satisfactory. Their real value, however, lies in the application to natural materials, especially as a check on the accuracy of chemical and microbiological determinations. Such tests have been done. A preliminary report of some of the results was presented to the 8th World's Poultry Congress in Copenhagen (Coates, Kon \& Shepheard, 1948), and a detailed account will be submitted for publication in this fournal.

Many details of technique have still to be investigated before the methods now described are perfected. For instance, the interrelationship of tryptophan and nicotinic acid in chick nutrition will have to be considered. Briggs (1945) found that the presence of gelatin in a synthetic diet greatly increased the requirement of the chick for nicotinic acid and that in these circumstances administration of tryptophan prevented nicotinic-acid deficiency. These findings were confirmed by Briggs, Groschke \& Lillie (1946), in whose experience the inclusion of certain proportions of arginine, glycine and alanine in diets devoid of nicotinic acid precipitated signs of deficiency. It may thus prove difficult, if not impossible, to measure the amount of nicotinic acid present in a diet, though the method here described may well serve to assess the activity of a foodstuff in terms of nicotinic acid. Similarly, the findings of Milligan \& Briggs ( I 949) that the chick can make use of panthenol instead of pantothenic acid will have to be investigated, as well as the question of the relative potencies of pyridoxin, pyridoxal and pyridoxamine. 
We have not yet found a suitable criterion of response for biotin, although the possibility is being considered of producing symptoms of deficiency earlier in the chick's life by inclusion of raw egg white in the diet.

When the present study was begun it was the opinion of many that the identification of the members of the vitamin B complex had been completed by the discovery of folic acid, but more recent work has shown that it is not so. We are studying at present the need to supplement our normal diet with strepogenin, vitamin $B_{12}$ and other components of the animal protein factor. We are working also on the determination of vitamin $\mathrm{B}_{12}$ itself (Coates, Harrison \& Kon, 1950; Black, Getty, Coates, Harrison \& Kon, 1950).

The very marked improvement in response of our chicks after granulation of the diets had been adopted is difficult to explain. As some wastage of food could not be avoided in our brooders it was not possible to keep accurate records of food consumption but, as far as could be judged, the consumption of a granulated diet did not greatly exceed that of the corresponding powdery diet, and the difference was certainly not sufficient to account for the very much better growth. The powdery diet was liable to cake on the chicks' beaks, which may have decreased its palatability and also resulted in greater wastage in the water troughs. The granulated diet, on the other hand, was easier to eat, and its granular nature may have slowed the rate of passage through the gut, particularly the gizzard, thereby increasing the efficiency of utilization. Our experience agrees with that of workers who, with practical poultry rations, found increase in rate of growth and efficiency of food utilization when pelleted diets were given instead of dry mash (Heywang \& Morgan, 1944; 'Temperton \& Dudley, 1948).

We have dealt so far with the assay of nicotinic acid, pyridoxin, riboflavin, pantothenic acid and folic acid, but the technique could almost certainly be adapted to other members of the vitamin B complex such as aneurin or choline. 'I'he unintentional production of what probably was a deficiency of isoleucine in chicks given blood meal as the main source of protein in their diet (see p. 209) suggests that the methods might be applied to the biological assay of amino-acids also.

It was not our intention in designing these methods that they should replace for routine analysis the simpler and more economical microbiological techniques. 'Their purpose was to provide a means of checking the validity of results obtained by chemical and microbiological methods. Work now in progress with various natural materials shows that, in fact, such a check is necessary.

\section{SUMMARY}

I. A synthetic diet was devised which, when fully supplemented with the known vitamins, supported nearly normal growth in chicks up to 4 weeks of age. When nicotinic acid (amide), pyridoxin, riboflavin, pantothenic acid, folic acid, or biotin was omitted the chicks developed typical signs of deficiency of the missing vitamin.

2. Dose-response curves were constructed for nicotinic acid, pyridoxin, riboflavin and pantothenic acid with change in body-weight, and for folic acid with change in $\mathrm{Hb}$ level, as the criterion of response. No measurable criterion was found for biotin within the first 4 weeks of the chick's life. 
M. E. COATES. S. K. KON AND E. E. SHEPHEARD. B-vitamin assays with chicks Plate I

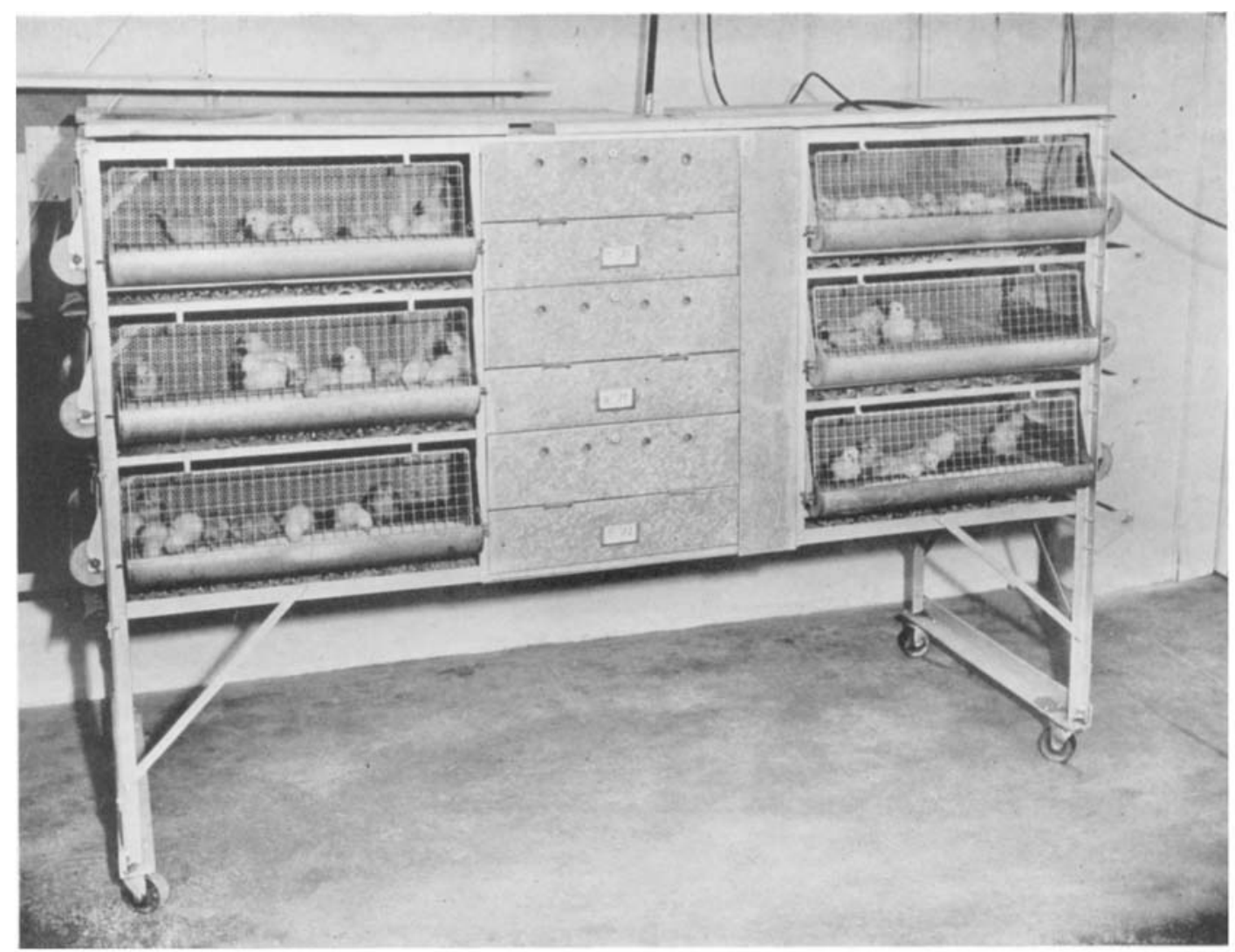

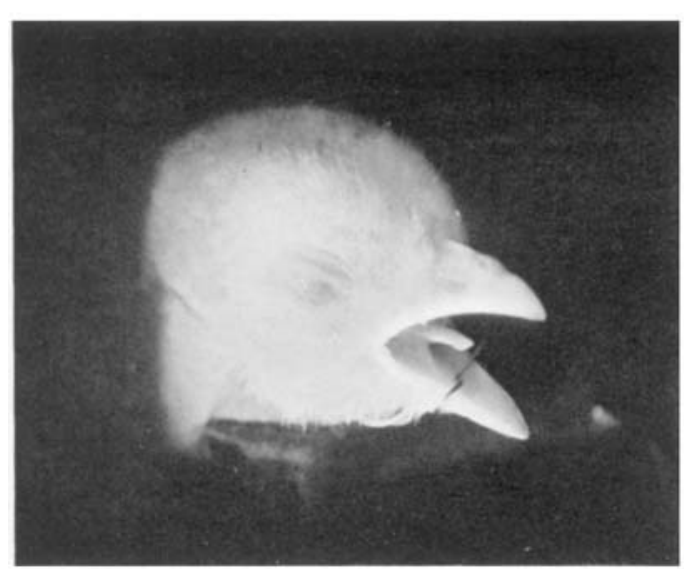

2

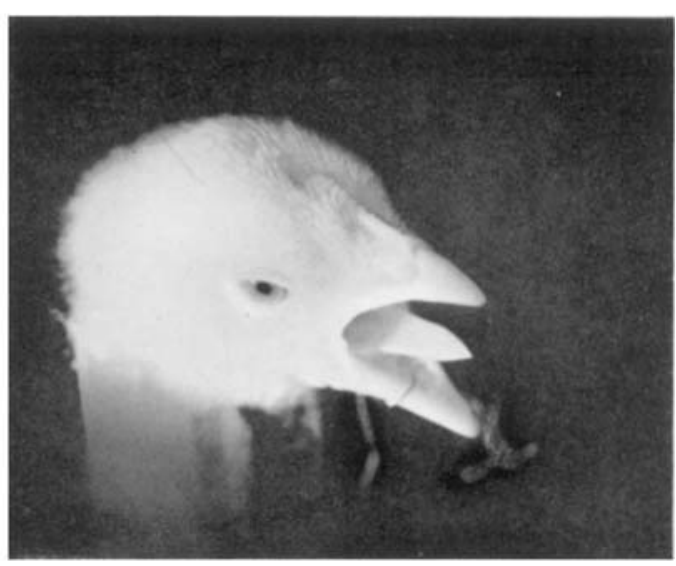

3

British fournal of Nutrition, Vol. 4, Nos. 2 and 3 


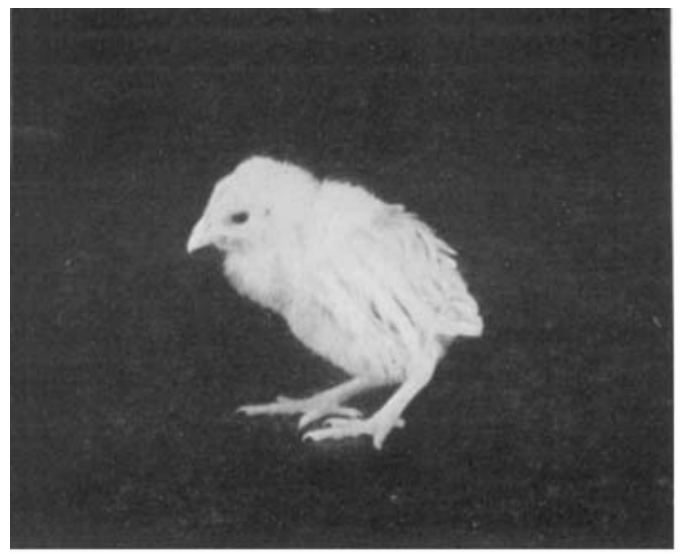

1

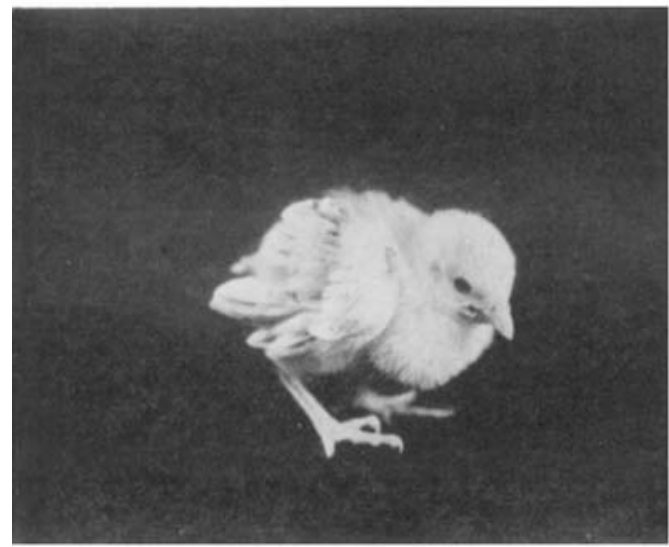

3

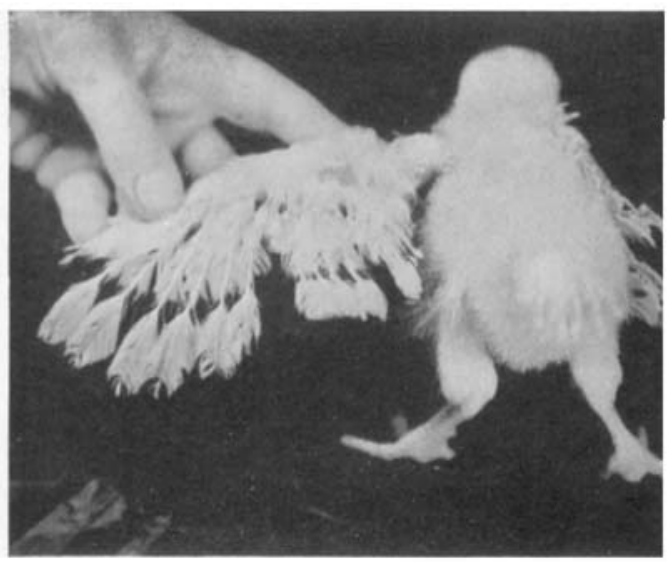

5

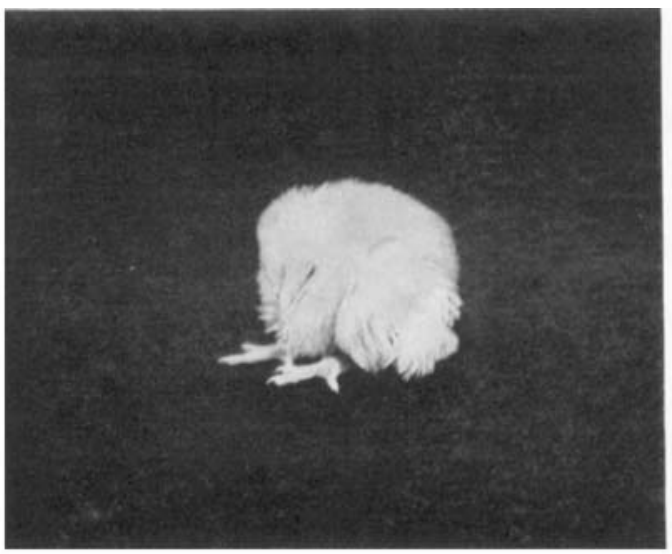

2

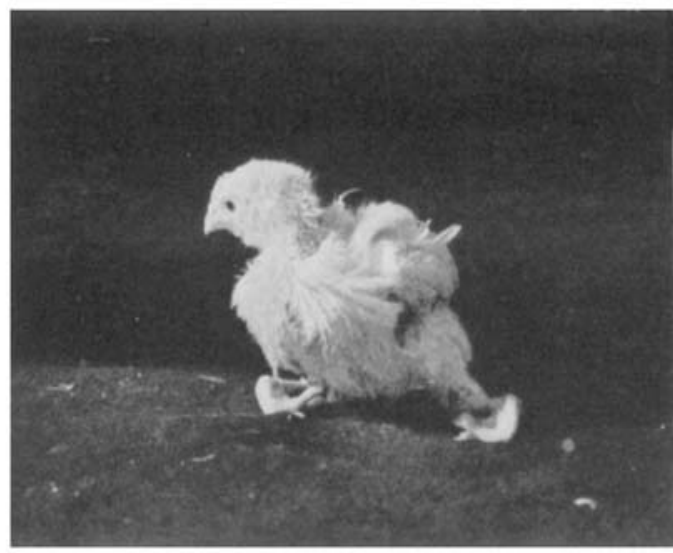

$+$

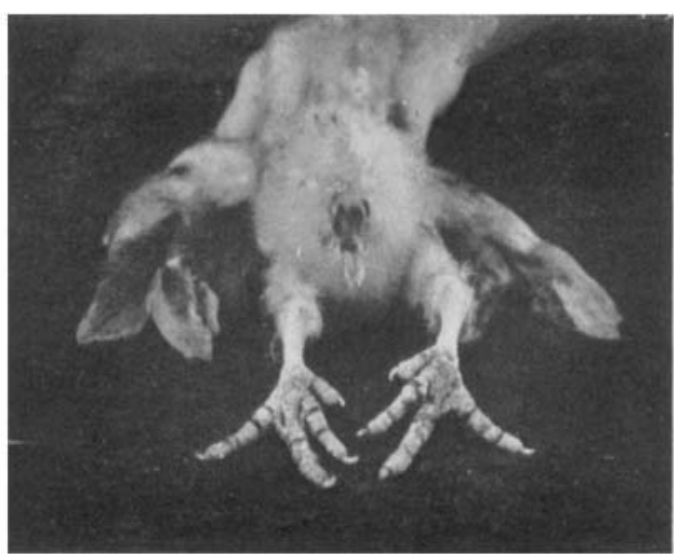

6

British Fournal of Nutrition, Vol. $4, N^{N o s} .2$ and 3 
3. The methods proved suitable for rigid statistical interpretation and yielded satisfactory estimates of potency of preparations of pure vitamins whose concentration was not disclosed until after the test.

4. A considerable improvement in response was obtained when the diet was given in granulated rather than in powdery form.

We are indebted to Drs J. W. G. Porter and S. Y. 'Thompson for some chemical determinations and for preparation of samples for test, to Mr F. W. Wilby for microbiological assays and to $\mathrm{Mr} \mathrm{N}$. Gruber for the photographs. We are grateful also to Mr G. H. Burgess, Miss P. Belcher and Mrs M. Gaymer for help with the chicks. We should like to acknowledge gifts of folic acid from Dr T. H. Jukes, Lederle Laboratories, and of liver extracts from Glaxo Laboratories Ltd. and British Drug Houses I,td.

\section{EXPLANATION OF PLATES}

\section{Plate I}

x. A modified brooder to contain twelve groups of ten to fifteen chicks.

2. A fourteen-day-old chick showing 'blunt tongue'.

3. A normal bird of the same age.

\section{Plate 2}

Photographs of chicks showing marked signs of deficiency of different vitamins of the B complex.

1. Nicotinic-acid deficiency after 20 days on diet.

2. Pyridoxin deficiency after 18 days on dict.

3. Pantothenic-acid deficiency after 24 day's on diet.

4. Riboflavin deficiency after 21 days on diet.

5. Folic-acid deficiency after 24 days on diet.

6. Biotin deficiency after 28 days on diet.

\section{REFERENCES}

Arnold, A. \& Filvehjem, C. A. (1938). \%. Nutrit. I5, 403.

Black, D. J. G., Getty, J., Coates, M. E., Harrison, G. F. \& Kon, S. K. (1950). Biochem. 7. 46, viii. Briggs, G. M. (1945). F. biol. Chem. 16r, 749.

Briggs, G. M., Groschke, A. C. \& I.illie, R. J. (I946). F. Nutrit. 32, 659.

Briggs, G. M. Jr., Luckey, T. D., Elvehjem, C. A. \& Hart, E. B. (1943). F. biol. Chem. I48, I63.

Briggs, G. M. Jr., Mills, R. C., Elvehjem, C. A. \& Hart, E. B. (1942). Proc. Soc. exp. Biol., N. Y., $51,59$. British Standards Institution (1940). Stand. Specif. Brit. Stand. Inst. no. 911.

Clark, W. M., Zoller, H. F., Dahlberg, A. O. \& Weimar, A. C. (1920). J. industr. Engng Chem. $12,1163$. Coates, M. E., Hall, H. S. \& Thiel, C. C. (1950). Brit. F. Nutrit. 4, 199.

Coates, M. E., Harrison, G. F. \& Kon, S. K. (1950). Biochem. Y. 46, vii.

Coates, M. E., Kon, S. K. \& Shepheard, E. E. (1948). World's Poult. Congr. vill, Copenhagen, p. 109.

Grau, C. R. (1945). Proc. Soc. exp. Biol., N.Y., 59, 177.

Grau, C. R. \& Almquist, H. J. (1944). Poult. Sci. 23, 486.

Harris, L. J. (1948-9). Brit. Y. Nutrit. 2, 362 .

Hegsted, D. M. (1946). F. Nutrit. 32, 467 .

Hegsted, D. M., Mills, R. C., Elvehjem, C. A. \& Hart, E. B. (194I). J. biol. Chem. 138, 459.

Heywang, B. W. \& Morgan, R. B. (19+4). Poult. Sci. 23, 16.

Hutchings, B. L., Bohonos, N. \& Peterson, W. H. (194I). Y. biol. Chem. I4I, 52 I.

Irwin, J. O. (1937). J. R. statist. Soc. Suppl. 4, 1.

Jukes, T. H. (1937). F. Nutrit. 14, 223.

Jukes, T. H. (194I). Y. Nutrit. 21, 193.

Jukes, T. H. (1947). Biol. Symp. 12, 258.

Jukes, T. H. \& Heitman, H. Jr. (I940). J. Nutrit. I9, 2 I.

Jukes, T. H. \& Stokstad, E. L. R. (1948). Physiol. Rev. 28, 5 I. 
Lepkovsky, S. \& Kratzer, F. H. (1942). F. Nutrit. 24, 515.

Lillie, R. J. \& Briggs, G. M. (1947). Poult. Sci. 26, 289.

Luckey, T. D., Briggs, G. M. Jr., Elvehjem, C. A. \& Hart, E. B. (1945). Proc. Soc. exp. Biol., N. Y., 58, 340.

Milligan, J. L. \& Briggs, G. M. (1949). Poult. Sci. 28, 202.

Norris, L. C., Wilgus, H. S., Ringrose, A. T., Heiman, V. \& Heuser, G. F. (1936). Bull. Cornell agric. Exp. Sta. no. 660.

Olsson, N. (1941). Studien über die Verwendbarkeit wachsender Küken zur Bestimmung des antirachitischen Effekts von Vitamin $D$ und ultraviolettem Licht. Lund: Gleerupska Universitetsbokhandeln.

Sarma, P. S., Snell, E. E. \& Elvehjem, C. A. (1946). Y. biol. Chem. 165, 55.

Schumacher, A. E., Heuser, G. F. \& Norris, L. C. (1940). F. biol. Chem. 135, 313.

Snell, E. E. \& Strong, F. M. (1939). Industr. Engng Chem. (Anal ed.), 11, 346.

Stokstad, E. L. R. \& Manning, P. D. V. (1938). F. biol. Chem. 125, 687.

'Student' (1908). Biometrika, 6, 1.

'Student' (1925). Metron, 5, 105.

Supplee, G. C., Flanigan, G. E., Hanford, Z. M. \& Ansbacher, S. (1936). f. biol. Chem. 113, 787.

Temperton, H. \& Dudley, F. J. (1948). Harper Adams Util. Poult. $\mathcal{F} .33,1$. 